
Vol. XIV.
May, 1911.
No. 159

\title{
ABSTRACTS FROM THE ORIGINAL ARTICLES
}

\section{ÜBEL DAS DRUCKÖL.}

\section{Von M. Yano, Kogakushi.}

Verf. hat eine grosse Menge Versuche über die Bereitung des Drucköles und seine Eigenschaften angestellt. Die Resultate sind unten zusammengefasst.

I. Das aus rohem Öle ohne Sikkativ gekochte Öl hat dieselben Eigenschaften, wenn sein specifisches Gewicht gleich bleibt.

2. Die Eigenschaften und Qualitäten des gekochten Öles kann man vom specifischen Gewichte ve; muten.

3. Je höher die Temperatur ist, desto schneller steigert sich das specifische Gewicht beim Kochen des Öles.

4. Die geeignete Temperatur für das Kochen liegt zwischen $310-320^{\circ} \mathrm{C}$.

5. Wenn die Luft auf der Oberfläche des Öles unter dem kochen stark einwirkt, wird das specifische Gewicht schneller gesteigert.

6. Unter denselben Bedingungen wird das specifische Gewicht in gleichem Grad gesteigert, deshalb kann man die Kochtemperatur sowie Dauer nach den Eigenschaften des Öles genau vermuten. 


\section{ON THE UTLLZATION OF THE ELECTROLYTIO CHLORING.}

\section{By Tsuneo Nohara, Rigakusli.}

Mostly the electrolytic chlorine is worked into bleaching powder, but there must be its overproduction. Hence the writer has investigated how to utilize the chlorine profitably. In the present report, the writer described some researches on the manufacture of sulphur monochloride, as plentiful sulphur cccurs in Japan. 